\title{
Purification of prothrombin complex proteins from human plasma in anion exchange resin using pseudoaffinity chromatography
}

\author{
Vinicius Watanabe Nakao ${ }^{*}$, Claudia Iwashita Verinaud, Gabriel Feliciano Pinna, André Conti Luiz, Isaías Raw, \\ Elisabeth AL Martins, Elisabeth Cheng
}

From 5th Congress of the Brazilian Biotechnology Society (SBBIOTEC)

Florianópolis, Brazil. 10-14 November 2013

\section{Background}

Prothrombin complex contains the vitamin $\mathrm{K}$ dependent coagulation factors II, VII, IX, X, protein C, and protein S. It has been used for the treatment of congenital coagulation disorders and is recommended for reversing oral anticoagulation [1]. Prothrombin complex proteins require $\mathrm{Ca}^{2+}$ to express their activities. The conformational change induced by $\mathrm{Ca}^{2+}$ finds a practical application in the purification processes by modifying the affinity of these proteins to chromatographic resins. The elution of proteins by variation of calcium concentration is called chromatography of pseudoaffinity [2]. In this study we exploit this property of the vitamin dependent coagulation factors to develop a new method for purification of prothrombin complex proteins from human plasma using an anion exchange resin.

\section{Methods}

Plasma was directly applied to the ANX Sepharose FF column, previously equilibrated with citrate buffer $25 \mathrm{mM}$ containing $\mathrm{NaCl} 85 \mathrm{mM}$ and $\mathrm{CaCl}_{2}, \mathrm{pH}$ 6. The unbound proteins were washed out with the same buffer. After a washing with citrate buffer containing $\mathrm{NaCl} 200 \mathrm{mM}$, elution was carried out in the same buffer with a linear calcium gradient from $2.5 \mathrm{mM}$ to $25 \mathrm{mM}$. Three different buffers were tested: citrate, Bis-Tris and MES. Finally, column was washed with citrate buffer containing 500 $\mathrm{mM} \mathrm{NaCl}$. Chromatographic fractions were analyzed by: activity of Protein $C$ using the chromogenic method as representative of the prothrombin complex proteins, protein content by the Bradford method, and SDS-PAGE.

Centro de Biotecnologia, Instituto Butantan - Av. Vital Brasil 1500, 05503-090, São Paulo, Brasil 